\section{KELAS REPERTOAR PADA PEMBELAJARAN GITAR}

\section{Herwin Yogo Wicaksono}

FBS Universitas Negeri Yogyakarta

\section{Abstrak}

Repertoire classes have not become a common practice in many informal institutions conducting guitar learning even though some formal institutions have done the practice. To implement repertoire classes needs appropriate time and places.

Repertoire classes regularly conducted are proven to improve students' motivation to learn, decrease their nervousness and increase their selfconfidence. Besides, such classes motivate them to compete in improving their skill and become places to socialize among them.

Key words: repertoire, guitar learning and students' self confidence

\section{A. Pendahuluan}

Gitar merupakan alat musik berdawai yang banyak digemari masyarakat. Alat musik yang sederhana itu mempunyai karakteristik tersendiri. Dari segi harga, alat musik gitar relatif terjangkau untuk masyarakat kita, karena harga gitar tersedia dari harga yang murah (puluhan ribu rupiah) sampai harga yang mahal (puluhan juta rupiah), sedangkan ditinjau dari teknik permainan alat musik gitar dapat dimainkan secara sederhana (untuk mengiringi / "genjrengan") sampai teknik permainan yang sulit (solo gitar).

Pada umumnya, masyarakat sudah mengetahui bahwa gitar dapat berfungsi sebagai alat musik pengiring dan alat musik tunggal. Namun demikian, untuk teknik permainan gitar tunggal (solo gitar) masih sedikit masyarakat yang dapat menguasainya. Kebanyakan masyarakat hanya menguasai teknik permainan gitar untuk iringan yang menggunakan teknik strumming ("genjrengan").

Dalam mempelajarai teknik permainan gitar untuk iringan, dapat dilakukan secara otodidak atau dapat juga dengan melihat orang lain kemudian menghafal pergerakan akor yang digunakan. Sementara itu, untuk mempelajari teknik permainan gitar tunggal pada umumnya dengan cara didampingi instruktur (guru), baik melalui lembaga informal seperti kursus-kursus musik maupun melalui sekolah formal, seperti Sekolah Menengah Musik, Institut Seni Musik Yogyakarta, maupun Jurusan Pendidikan Seni Musik FBS Universitas Negeri Yogyakarta. Dalam lembaga informal maupun formal tersebut fokus pembelajaran lebih banyak pada teknik permainan gitar tunggal.

Jurusan Pendidikan Seni Musik FBS Universitas Negeri Yogyakarta sebagai lembaga pendidikan yang menghasilkan guru-guru musik, di dalam kurikulumnya menempatkan mata kuliah praktik gitar sebagai prioritas salah satu alat musik yang wajib dikuasai oleh mahasiswa. Hal ini disebabkan oleh praktisnya alat musik gitar sebagai alat musik melodi, ritmis, dan harmoni yang sangat diminati oleh masyarakat terutama para remaja.

Pembelajaran praktik alat musik gitar pada Jurusan Pendidikan Seni Musik FBS UNY bertujuan agar mahasiswa mampu menguasai teknik dasar bermain gitar, sehingga apabila terjun di masyarakat tidak canggung lagi.

Pelaksanaan pembelajaran mata kuliah praktik alat musik gitar dapat dilaksanakan dengan dua cara. Pertama, dengan privat yaitu satu dosen mengajar satu mahasiswa. Kedua, dengan cara kelompok, yaitu satu dosen mengajar banyak mahasiswa. Pada Jurusan Pendidikan Seni Musik FBS UNY, praktik gitar dilaksanakan dengan sistem kelompok dimana setiap kelompoknya terdiri dari + 10 mahasiswa. Pelaksanaan sistem kelompok ini pada dasarnya mempunyai kelebihan dan kelemahan. Kelemahan sistem kelompok antara lain adalah kondisi dan latar belakang mahasiswa yang heterogen dalam satu kelompok, sehingga perhatian pengajar (dosen) menjadi terbagi dan tidak merata. Hal ini berakibat juga terhadap prestasi belajar mahasiswa yang menjadi kurang maksimal. Kelebihan dari sistem kelompok yaitu mahasiswa menjadi terbiasa bermain kelompok dan saling memberi motivasi atau saling memacu.

Namun demikian, kenyataan yang ada dalam pelaksanaan pembelajaran sistem kelompok pada praktik alat musik gitar adalah mahasiswa menjadi kurang serius dan cenderung saling tergantung satu sama lain. Hal ini dapat terdeteksi apabila mahasiswa ditunjuk untuk memainkan sebuah karya musik (lagu) dari tugas yang telah diberikan secara bersama-sama, mereka dapat bermain dengan lancar, namun apabila ditunjuk secara perorangan untuk memainkan lagu kebanyakan dari mereka terlihat nervous dan bermain dengan tersendat-sendat sehingga terkesan tidak siap dalam memainkan lagu. Untuk mengatasi kondisi tersebut dan untuk meningkatkan hasil pembelajaran praktik gitar pada mahasiswa Jurusan Pendidikan Seni Musik FBS UNY, diperlukan adanya apresiasi dari dosen maupun sesama mahasiswa. Dengan demikian, setiap mahasiswa akan mendapat masukan berupa kritik dan apresiasi yang positif dari dosen dan sesama mahasiswa yang lain. Di samping itu, dosen dapat juga memberi contoh secara utuh baik dari segi teknik maupun interpretasi, sehingga akan menambah kredibilitasnya.

\section{B. Pembelajaran Praktik Gitar}

Istilah pembelajaran sebenarnya merupakan pengembangan atau penyempurnaan dari pengajaran. Pembelajaran merupakan proses belajar mengajar yang tujuannya agar siswa/mahasiswa berusaha untuk memperoleh atau mencapai tujuan tertentu. 
Menurut Samsudin melalui Silaen, (1996 : 6); istilah pembelajaran sebagai kerangka konseptual yang melukiskan prosedur yang sistematis dalam mengorganisasikan pengalaman belajar untuk mencapai tujuan tertentu cara dan prosedur yang ditempuh merupakan kegiatan belajar mengajar.

Pembelajaran praktik gitar mempunyai karakteristik tersendiri. Hal ini disebabkan pembelajar belum tentu mempunyai anatomi yang sesuai atau cocok untuk belajar alat musik gitar, baik anatomi jari tangan kiri, jari tangan kanan, maupun kuku jari tangan kanan, sehingga untuk mencapai hasil yang baik dalam penguasaan alat musik gitar pembelajar mengalami banyak kendala terutama pada mata kuliah gitar yang wajib tempuh. Langkah yang perlu diambil yaitu dengan variasi dalam pembelajaran, agar menarik minat pembelajar sehingga bersemangat dan mandiri dalam berlatih.

Menurut Gunawan (1993 : 9-10), ada enam unsur untuk membuat pengajaran menarik, yaitu :

1) Menekan kebingungan, maksudnya jangan sekali-kali pembelajar menghadapi masalah yang tidak terpecahkan.

2) Merasa mencapai kemajuan, maksudnya bila pembelajar mendapat kemajuan biasanya akan tertarik dengan kegiatannya.

3) Lomba atau persaingan sehat. Semangat berlomba menambah kenikmatan dalam segala bentuk kegiatan.

4) Latihan berbentuk lomba. Latihan yang digarap demikian akan membuat pembelajar semakin tertarik.

5) Hubungan pengajar dan pembelajar. Hubungan yang positif antara pengajar dan pembelajar menyumbang kemenarikan yang sangat besar dalam kegiatan belajar.

6) Bervariasi, yaitu dengan memvariasikan pelaksanaan kegiatan agar tidak monoton.

Berdasarkan pengalaman di lapangan, dalam pembelajaran praktik gitar yang individual (privat), tingkat keberhasilannya lebih baik jika dibandingkan dengan pembelajaran praktik gitar yang kelompok. Hal ini disebabkan fokus pengajar dan pembelajar pada pembelajaran individual lebih baik dan terkonsentrasi pada satu sasaran.

Sampai saat ini masih sedikit pengajar praktik alat musik termasuk gitar yang memikirkan bagaimana menambah kepercayaan diri siswa. Kebanyakan pengajar musik memikirkan dan mengajarkan tentang bagaimana meningkatkan keterampilan teknik yang meliputi kerapian jari baik tangan kanan maupun tangan kiri, ketepatan ritme, penjarian, tone color, ekspresi, dan interpretasi.

Pada Jurusan Pendidikan Seni Musik FBS UNY, praktik pembelajaran gitar digolongkan menjadi dua kelompok yaitu pada kelompok wajib dan kelompok pilihan. Pada kelompok wajib ada dua mata kuliah yaitu Gitar Dasar dan Gitar Dasar Lanjut, sedangkan pada kelompok pilihan ada satu mata kuliah yaitu Praktik Individual Mayor (PIM) yang mencakup enam tingkatan (dari PIM I sampai dengan PIM VI).

Bagi mahasiswa yang memilih mata kuliah PIM Gitar, pelaksanaan proses belajar mengajarnya relatif lebih baik dan lancar. Hal ini disebabkan motivasi mahasiswa dalam belajar lebih baik karena memang sesuai dengan pilihannya, sedangkan pada mata kuliah Gitar Dasar dan Gitar Dasar Lanjut yang merupakan kuliah wajib tempuh, pelaksanaannya lebih sering ditemui hambatan. Hambatan yang paling banyak ditemui antara lain motivasi yang kurang, anatomi yang tidak sesuai dengan instrumen (sering terjadi pada mahasiswa putri, seperti jari-jari tangan yang kecil dan pendek), dan gitar yang tidak standar.

Dari segi materi, pembelajaran praktik Gitar Dasar dan Gitar Dasar Lanjut lebih menitik beratkan pada kemampuan teknik dasar bermain gitar yang meliputi kemampuan mengiringi lagu-lagu pop dengan berbagai pola iringan baik berupa strumming atau lebih dikenal dengan sebutan "genjrengan" maupun dengan petikan, serta lagu untuk gitar tunggal dengan teknik yang relatif sederhana. Sementara itu, materi pembelajaran pada mata kuliah PIM Gitar hanya ditekankan pada penguasaan keterampilan bermain gitar tunggal dengan teknik permainan yang jauh lebih tinggi dan komplek. Pada mata kuliah PIM inilah mahasiswa dituntut keseriusan, motivasi dan kemandirian yang tinggi untuk dapat memperoleh hasil yang maksimal.

C. Pelaksanaan Kelas Repertoar

1. Konsep dan Pengertian

Repertoar berasal dari bahasa Perancis yaitu Repertoire. Menurut Kodijat (1983: 62), repertoar berarti berbekalan komposisi yang ada pada seorang seniman penyelenggara pagelaran musik. Repertoar dapat juga berarti kumpulan lagu-lagu (Last, 1989:134). Menurut Soeharto (1982:114) repertoar berarti sejumlah komposisi yang harus disiapkan untuk sebuah acara atau program tertentu. Sedangkan pengertian Kelas Repertoar di kalangan pemusik adalah kegiatan belajar berupa bermain musik atau membawakan komposisi musik baik secara individu maupun kelompok yang dilaksanakan di dalam kelas secara bergantian disertai dengan kritik dan saran pada setiap akhir permainan.

Kegiatan ini sangat baik untuk membantu dan menambah pengalaman pribadi bagi mahasiswa untuk tampil di depan umum sekaligus meningkatkan dan mendalami penguasaan terhadap alat musik. Di samping itu, kegiatan belajar mengajar menjadi bervariasi, bahkan hubungan antara pengajar dan pembelajar menjadi positif. 
2. Faktor-faktor yang Berkaitan dengan Kelas Repertoar

Pelaksanaan kelas repertoar pada pembelajaran praktik alat musik lebih mudah diterapkan pada lembaga formal. Hal ini dikarenakan pada lembaga formal menyediakan tempat dan waktu yang lebih mudah koordinasinya jika dibandingkan dengan lembaga non formal seperti kursus-kursus musik.

Pada umumnya kelas repertoar hanya dilaksanakan pada lembaga pendidikan musik formal yang pelaksanaannya disisipkan diantara jam-jam pelajaran (kuliah). Di Jurusan Pendidikan Seni Musik FBS UNY yang selalu rutin melaksanakan kelas repertoar pada pembelajaran mata kuliah praktik adalah mata kuliah praktik gitar yang meliputi mata kuliah Gitar Dasar, Gitar Dasar Lanjut, maupun mata kuliah PIM Gitar, sedangkan mata kuliah praktik yang lain yang terselenggara di Jurusan Pendidikan Seni Musik sampai saat ini belum dapat melaksanakan kelas repertoar dengan baik.

Untuk memperoleh hasil yang maksimal dalam pelaksanaan kelas repertoar, maka perlu memperhatikan hal-hal sebagai berikut :

\section{a. Tempat yang Memadai}

Tempat yang baik untuk melaksanakan kelas repertoar adalah yang menyerupai panggung pementasan namun berukuran lebih kecil. Di samping itu, juga kedap suara dan sebaiknya ber AC sehingga terhindar dari suara-suara lain yang dapat mengganggu konsntrasi jalannya pelaksanaan kelas repertoar khususnya saat peserta tampil.

Ruangan dapat berbentuk persegi panjang ataupun berbentuk bujur sangkar, yang penting dalam hal ini terdapat trap yang memisahkan antara peserta kelas repertoar yang tampil dengan peserta kelas repertoar yang menonton. Dengan tempat yang menyerupai panggung pementasan tersebut, para mahasiswa seolaholah berimajinasi sedang tampil pada panggung yang sebenarnya.

b. Waktu yang Cukup

Waktu yang dibutuhkan untuk pelaksanaan kelas repertoar minimal satu jam mata kuliah atau setara dengan 100 menit, namun yang terbaik adalah sesuai dengan jumlah peserta kelas repertoar yang akan tampil sehingga semua peserta dapat membawakan repertoar lagu yang telah disiapkan. Di samping itu, dengan waktu yang cukup ada kesempatan dari sesama peserta kelas repertoar maupun pembimbing untuk memberikan masukan baik yang bersifat teknis, sikap, ekspresi, maupun interpretasi yang berguna untuk penyempurnaan dalam penguasaan bermain gitar pada peserta yang tampil.

c. Repertoar Lagu yang Variatif

Dalam pelaksanaan kelas repertoar suasana yang baik akan menentukan keberhasilan yang ingin dicapai. Dengan lagu yang bermacam-macam (variatif) yang ditampilkan dalam kelas repertoar akan menambah apresiasi dan mengurangi rasa bosan bagi seluruh peserta. Dengan demikian, suasana akan menjadi lebih kondusif dan peserta lebih bersemangat.

Manfaat lain dari variatifnya lagu yang ditampilkan dalam Kelas repertoar akan menambah penguasaan interpretasi peserta, sehingga peserta memiliki pengalaman yang lebih baik dalam apresiasi lagu dari berbagai jaman.

\section{d. Jumlah Peserta}

Jumlah peserta dalam pelaksanaan kelas repertoar sebaiknya minimal 15 orang. Hal ini dimaksudkan agar peserta yang tampil dalam kelas repertoar dapat disaksikan oleh cukup banyak penonton. Jika jumlah peserta kelas repertoar kurang dari 15 orang, maka dikhawatirkan tidak berpengaruh banyak terhadap kepercayaan diri peserta yang tampil. Sebaliknya, semakin banyak peserta kelas repertoar pada umumnya akan membuat peserta yang tampil menjadi nervous (grogi). Dengan demikian, dengan tampilnya peserta pada kelas repertoar yang diikuti oleh lebih dari 15 orang peserta akan melatih mental peserta menjadi lebih baik, sehingga apabila kelak memberikan contoh di depan kelas atau tampil pada suatu pertunjukan maka sudah lebih percaya diri.

e. Jumlah Pembimbing

Dalam pelaksanaan kelas repertoar jumlah pembimbing sebaiknya lebih dari satu orang. Hal ini dimaksudkan dengan jumlah pembimbing yang lebih dari satu (2 atau 3 orang), maka akan dapat menambah pengetahuan dan pengalamannya kepada peserta kelas repertoar menjadi lebih lengkap. Pengetahuan dan pengalaman pembimbing dalam kelas repertoar sangat dibutuhkan untuk dapat memberikan masukan baik berupa pembetulan teknik permainan maupun interpretasi lagu yang merupakan tingkat tersulit dalam menampilkan sebuah karya musik. Dengan jumlah pembimbing yang lebih dari satu akan dapat saling melengkapi satu sama lain dalam memberikan masukan. f. Peran Aktif Peserta Kelas Repertoar

Dalam pelaksanaan kelas repertoar, mahasiswa peserta kegiatan tersebut juga dituntut aktif untuk turut berperan serta memberikan masukan baik berupa kritik maupun saran yang tentu saja bersifat membangun. Hal itu dimaksudkan untuk menanamkan sikap kritis dan berani mengemukakan pendapat yang baik dalam suatu forum. Di samping itu, tidak hanya dapat memberikan keuntungan bagi peserta yang tampil, tetapi juga memberikan keuntungan bagi mahasiswa peserta yang memberikan masukan tersebut. Mahasiswa peserta kelas repertoar yang memberi masukan, keuntungan yang diperoleh berupa adanya sikap kritis dan berani untuk mengemukakan pendapat yang baik, sehingga sikap positif yang telah ditanamkan tersebut dapat berguna kelak pada saat mahasiswa terjun di masyarakat. 
3. Langkah-Langkah dalam Kegiatan Kelas Repertoar

Ada beberapa langkah yang perlu disiapkan untuk melaksanakan kegiatan kelas repertoar. Langkah-langkah tersebut adalah : 1) perencanaan; 2) pelaksanaan, dan 3) evaluasi.

a. Merencanakan Waktu dan Tempat Pelaksanaan

Waktu pelaksanaan kegiatan kelas repertoar perlu direncanakan terlebih dahulu karena melibatkan kelas paralel, karena masing-masing mahasiswa dari kelompok paralel tersebut mempunyai waktu yang berbeda-beda. Oleh karena itu, perlu adanya kesepakatan untuk menentukan hari dan jam pelaksanaan. Selain itu, juga menentukan tempat pelaksanaan kegiatan Kelas repertoar.

Sebaiknya kelas repertoar diselenggarakan pada jam 09.00 - 11.00. Hal ini dimaksudkan pada jam tersebut mahasiswa dapat melakukan pemanasan sebelum mengikuti kelas repertoar. Di samping itu, kondisi mahasiswa juga masih semangat dan lebih fokus untuk mengikuti kuliah.

b. Pelaksanaan Kelas Repertoar

Dalam pelaksanaan kelas repertoar, perlu diatur urutan mahasiswa yang akan tampil, termasuk tempat duduk para pembimbing dan mahasiswa peserta kelas repertoar. Tempat duduk para pembimbing sebaiknya menempati posisi paling belakang. Hal itu dimaksudkan agar pembimbing dapat mengawasi dan mengontrol mahasiswa peserta yang tidak tampil agar mahasiswa tersebut dapat fokus memperhatikan mahasiswa peserta yang sedang tampil. Di samping itu, pembimbing juga dapat mengontrol sejauh mana kekuatan tone color dari mahasiswa yang tampil. Posisi duduk pelaksanaan kegiatan kelas repertoar dapat dilihat pada gambar berikut.

Denah Pelaksanaan Kelas Repertoar pada Pembelajaran Gitar

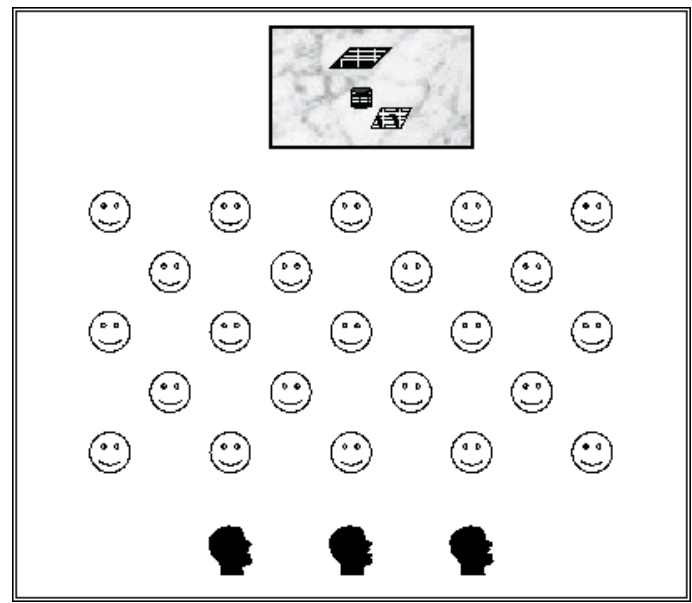

Imaji, Vol.4, No.2, Agustus $2006: 177$ - 186
Keterangan :

$\begin{array}{lll}\square & \text { : Panggung mini } & \text { : Mahasiswa penonton } \\ \text { 辰 } & \text { : Kursi } & \text { : Pembimbing } \\ \text { 画 } & \text { : Footstool } & \end{array}$

Sebaiknya dalam mengikuti kegiatan kelas repertoar, perlu disampaikan tata tertib terlebih dahulu. Tata tertib yang meliputi hal-hal sebagai berikut.

a) cara memberikan kritik dan saran,

b) saran-saran yang diberikan, baik berupa teknik maupun interpretasi,

c) sikap saling menghargai, pada waktu mahasiswa peserta tampil, mahasiswa

lain memperhatikan sehingga dapat memberikan masukan baik berupa kritik maupun saran.

Tidak kalah penting dalam persiapan menjelang pelaksanaan kelas repertoar, mahasiswa peserta kelas repertoar menyelaraskan tuning masingmasing gitar dengan standar nada " $\mathrm{a}=440 \mathrm{~Hz}$ ". Hal ini dimaksudkan agar suara

yang dihasilkan oleh masing-masing penampil standar dan sekaligus dapat melatih mahasiswa untuk terbiasa mendengarkan nada-nada yang baik.

Mahasiswa peserta kelas repertoar yang tampil, sebaiknya dimulai dari tingkat keterampilan yang rendah dan diakhiri dengan tingkat keterampilan yang tinggi. Dengan dimulainya dari keterampilan terendah terlebih dahulu akan menjaga mahasiswa yang memiliki ketarampilan rendah menjadi tidak gugup jika melihat penampilan mahasiswa dengan tingkat keterampilan yang lebih tinggi.

c. Evaluasi

Setiap akhir pelaksanaan kelas repertoar, perlu disediakan waktu 10 - 15 menit untuk memberikan evaluasi terhadap kelas repertoar yang telah diselenggarakan. Evaluasi berupa tanggapan keseluruhan tentang saran-saran dan kritik yang telah diberikan oleh peserta terhadap penampil maupun jalannya pelaksanaan secara keseluruhan. Dalam evaluasi ini pembimbing perlu memberikan penghargaan kepada mahasiswa yang tampil baik. Selain itu, mahasiswa yang memberikan kritik dan saran yang baik perlu juga diberikan penghargaan. Dengan penghargaan-penghargaan yang diberikan tersebut akan sangat berguna bagi mahasiswa untuk selalu meningkatkan kemampuannya dalam pelaksanaan kelas repertoar selanjutnya baik sebagai penampil maupun sebagai pemberi kritik dan saran.

Apabila memungkinkan sebaiknya pembimbing juga dapat memberikan contoh dengan memainkan sebuah repertoar secara utuh dengan teknik dan interpretasi yang baik, sehingga peserta kelas repertoar dapat lebih memahami bagaimana memainkan sebuah karya musik dengan teknik dan interpretasi yang benar.

Kelas Repertoar Pada Pembelajaran Gitar (Herwin Yogo Wicaksono) 


\section{Manfaat Kelas Repertoar}

Pertanyaan yang seringkali muncul dari mahasiswa dalam pembelajaran praktik instrumen gitar adalah bagaimana caranya menghilangkan rasa "grogi" khususnya pada saat bermain dan dilihat oleh banyak orang.

Perasaan "grogi" pada waktu tampil di depan banyak orang adalah merupakan hal yang wajar terutama bagi pemula. Cara yang terbaik untuk mengurangi dan menghilangkan rasa "grogi" adalah dengan membiasakan diri sesering mungkin tampil di hadapan orang banyak, salah satu caranya adalah mengikuti kelas repertoar. Hamalik (1989:31) mengemukakan bahwa faktor pengalaman merupakan bagian yang penting dalam proses belajar.

Berdasarkan hasil penelitian yang pernah dilakukan, kelas repertoar dapat meningkatkan motivasi mahasiswa dalam mengikuti mata kuliah praktik gitar. Hal ini dapat dilihat dari kesiapan dari awal kuliah yang antara lain meliputi kehadiran, tuning gitar, dan kesiapan dalam tugas-tugas terstruktur. Selain itu dapat juga tercermin dari tingkat kelancaran dalam memainkan lagu yang ditugaskan, karena untuk dapat bermain lancar sampai taraf baik (ahli) diperlukan latihan mandiri yang rutin dan dalam frekuensi yang banyak. Hal ini senada dengan pendapat Goleman (1999:111) bahwa untuk menjadi pemain yang hebat seperti musikus kelas dunia, diperlukan adanya kemampuan memotivasi diri untuk tak hentihentinya berlatih secara rutin. Selanjutnya Winkel (1986:28) berpendapat bahwa satu-satunya jalan menuju tujuan yang ingin dicapai ialah belajar; tanpa belajar, tidak mungkin menjadi ahli.

Dengan mengikuti kelas repertoar sebagian besar mahasiswa menyatakan bahwa kelas repertoar dapat mengurangi rasa "grogi" dan dapat meningkatkan rasa percaya diri dalam bermain gitar di depan kelas. Hal ini tercermin juga dalam pelaksanaan kelas repertoar lanjutan tanpa diminta tampil, mereka tampil dengan sendirinya bahkan dengan membawakan lebih dari satu lagu.

\section{E. Penutup}

Percaya diri merupakan sesuatu yang sangat diperlukan untuk meraih kesuksesan di berbagai bidang. Percaya diri tersebut tidak dengan sendirinya tumbuh dalam diri seseorang, tetapi perlu dilatih sedini mungkin sesuai dengan latar belakang masing-masing individu..

Kelas repertoar merupakan salah satu sarana yang baik untuk meningkatkan rasa percaya diri bagi para pemain musik baik dalam mempertunjukkan keterampilannya maupun dalam pergaulan sehari-hari. Di samping itu, melalui kelas repertoar juga dapat ditanamkan sosialisasi diri sesama mahasiswa di dalam kehidupan bermusik dan merupakan tempat komunikasi antar kelompok yang berbeda, sehingga dapat saling menukar pengalaman.
Upaya mensosialisasikan pembelajaran kelas repertoar dalam mata kuliah praktik musik sebaiknya tidak hanya dilaksanakan oleh mata kuliah praktik gitar saja tetapi juga dilaksanakan oleh mata kuliah praktik instrumen yang lain. Hal ini mengingat bahwa manfaat kelas repertoar dapat mengurangi rasa "grogi", dan menambah motivasi belajar. Selain itu, kelas repertoar dapat menambah tingkat kesiapan mahasiswa dalam menghadapi ujian akhir semester, karena berdasarkan hasil penelitian yang telah dilakukan terlihat hasil ujian semester mahasiswa yang mengikuti kelas repertoar semua lulus dengan sebagian besar memperoleh nilai baik.

\section{Daftar Pustaka}

Goleman, Daniel. 1999. Emotional Intelligence. Jakarta : PT. Gramedia Pustaka Utama.

Hamalik, Oemar. 1989. Media Pendidikan. Bandung. PT. Citra Aditya Bakti. Kodijat, Latifah. 1983. Istilah-Istilah Musik. Jakarta : Djambatan.

Last, Joan. 1989. Pianis Remaja, Buku Pegangan Untuk Guru dan Murid. Jakarta : PT. Gramedia.

Silaen, H. T, dkk. 1996. "Upaya Mengembangkan Model Pembelajaran Teori Musik Melalui Lagu yang Dikuasai Siswa bagi Guru-Guru Musik Di SMP Di Daerah Istimewa Yogyakarta". Penelitian Tindakan. IKIP Yogyakarta.

Soeharto, M. 1982. Membina Paduan Suara dan Grup Vokal. Jakarta : PT. Gramedia. 
